\title{
The Gut Microbiota in Celiac Disease and Probiotics
}

\author{
Richa Chibbar and Levinus A. Dieleman * \\ Division of Gastroenterology, Department of Medicine, University of Alberta, Edmonton, AB T6G 2X8, Canada; \\ chibbar@ualberta.ca \\ * Correspondence: 1.dieleman@ualberta.ca
}

Received: 11 September 2019; Accepted: 2 October 2019; Published: 5 October 2019

\begin{abstract}
Celiac disease (CeD) is an immune-mediated enteropathy, and unique in that the specific trigger is known: gluten. The current mainstay of therapy is a gluten-free diet (GFD). As novel therapies are being developed, complementary strategies are also being studied, such as modulation of the gut microbiome. The gut microbiota is involved in the initiation and perpetuation of intestinal inflammation in several chronic diseases. Intestinal dysbiosis has been reported in $\mathrm{CeD}$ patients, untreated or treated with GFD, compared to healthy subjects. Several studies have identified differential bacterial populations associated with $\mathrm{CeD}$ patients and healthy subjects. However, it is still not clear if intestinal dysbiosis is the cause or effect of CeD. Probiotics have also been considered as a strategy to modulate the gut microbiome to an anti-inflammatory state. However, there is a paucity of data to support their use in treating $\mathrm{CeD}$. Further studies are needed with therapeutic microbial formulations combined with human trials on the use of probiotics to treat $\mathrm{CeD}$ by restoring the gut microbiome to an anti-inflammatory state.
\end{abstract}

Keywords: Celiac disease; probiotics; gut microbiota

\section{Introduction}

Celiac disease $(\mathrm{CeD})$ is an immune mediated enteropathy triggered by ingestion of gluten in genetically predisposed individuals carrying human leucocyte antigen (HLA) DQ2 or DQ8. The current mainstay of treatment is adherence to a strict gluten-free diet (GFD) [1-4]. The global prevalence of $\mathrm{CeD}$ has been increasing worldwide, and in the North America the prevalence increased five-fold mirroring the increase in Inflammatory Bowel Disease (IBD) [5-9].

The key genetic elements (HLA-DQ2 and HLA-DQ8), the auto-antigen (tissue transglutaminase 2 ), and the external trigger (gluten) causing $\mathrm{CeD}$ are fairly well established. HLA-DQ2/8 is a common genotype and is noted in approximately $35 \%$ of the population, and approximately $3 \%$ of individuals develop $\mathrm{CeD}$ upon gluten exposure, suggesting a role for other factors in the development of $\mathrm{CeD}$ [10-13]. Growing evidence suggests that gut microbiota is closely related to digestive tract diseases, including $\mathrm{CeD}[14,15]$. The gut microbiota plays a crucial role in mucosal differentiation, function, energy generation, and modulation of innate and adaptive system [16-18]. Alterations, probably due to improved hygiene and reduced exposure to various microorganisms, have been implicated in the pathogenesis of IBD [19]. Similarly, changes in the gut microbiome in HLA-DQ2/8 individuals can alter processing of gluten in the intestinal lumen, affect intestinal barrier, innate or adaptive immune responses, and may cause or contribute to gluten sensitive enteropathy [20]. As innovative therapies are developed, there is a paucity in understanding the role of the gut microbiota in $\mathrm{CeD}$, specifically pathogenesis and clinical course. It is also unclear if modulation of the gut microbiome alters the natural history of $\mathrm{CeD}$. In this review, we will discuss the association of gut microbiota in CeD. 


\section{Pathogenesis of Celiac Disease:}

In genetically susceptible patients, the pathogenesis of $\mathrm{CeD}$ starts with the ingestion of gluten-containing foods, which are incompletely digested in the intestinal lumen into potentially immunogenic gluten derived peptides (10- > 30 amino acids in size). Immunogenicity of these peptides varies, with 13-, 19- and 33-mers being more immunogenic and triggering immune response associated with $\mathrm{CeD}$. These peptides contain six copies of different epitopes to which most individuals react [20-22]. Gliadin peptides containing nine or less amino acids have reduced immunogenicity [23]. Some of the commensal duodenal microbiota also have peptidase activity and break gliadins into smaller peptides $[24,25]$.

To initiate the immune response, peptides translocate to the lamina propria by the paracellular route that involves the protein 'zonulin'. Gliadin peptides bind to chemokine receptor, C-X-C motif chemokine receptor 3 (CXCR3) on epithelial cells, upregulate zonulin, and disassemble tight junctions leading to increased permeability [26-28]. Another pathway is transcellular, mediated by secretory immunoglobulin A (IgA) with the help of transferrin receptor (CD71) expressed on luminal surface of epithelial cells [29]. In the lamina propria, intestinal tissue transglutaminase (tTG) reacts with gliadin peptides to deaminate them to negatively charged glutamic acid residues that are highly immunogenic. These residues are recognized and processed by the HLADQ2 and HLA DQ8 bearing antigen presenting cells. The deaminated peptides and tTG complex activate $\mathrm{CD}^{+} \mathrm{T}$ cells to generate antibodies against gliadin and tTG [30]. HLA-DQ2 and DQ8 variants enhance immune cell activation and autoimmunity by binding more tightly to gliadin peptides, thus accounting for $50 \%$ of genetic susceptibility [31]. Though non-HLA variants also regulate the structure and function of immune cells, it modestly increases the risk of CeD [32].

Innate immunity has an initial role in the development of $\mathrm{CeD}$. Ingestion of gluten containing foods increase Interleukin-15 (IL-15) production causing polarization of dendritic cells, altering T-cell receptor-alpha beta intraepithelial lymphocytes (IELs) in the epithelium and damage to intestinal tissue $[33,34]$. Dysregulated interferon (IFN)- $\gamma$ expression stimulates natural killer (NK) cells, $\mathrm{CD}^{+} \mathrm{T}$ cell, and dendritic cell activation. The typical immune systems response is neutrophil infiltration and IL-8 release from the epithelium and immune cells [34]. Gliadin stimulates macrophage production of TNF- $\alpha$, IL-8, RANTES, IL-1 $\beta$, and nitric oxide. Alpha-amylase trypsin inhibitors also stimulate innate immunity through Toll-like receptors (TLR), myeloid differentiation factor-2 (MyD88), and CD14 complex [34]. Genome-wide association studies identified additional 39 non-HLA loci involved in immune function and confer CeD risk. Some of these non-HLA loci also regulate bacterial colonization and sensing [32]. Pathogenic bacteria associated immunogenicity is dependent on TLR transmembrane proteins. After recognition of pathogen, they activate innate immune system. Normal intestinal commensal bacteria do not activate immune system due to downregulation of TLR. Thus, there are similarities in activation of the. innate immune pathway in both, during invasion by pathogenic microorganism or autoimmunity by gliadin peptide due to loss of self-tolerance, as in both states there is an increased expression of TLR, release of pro-inflammatory cytokines and induction of NF- $\mathrm{k} \beta$. Increased TLR4 and TLR2 expression is also associated with both Inflammatory Bowel Disease (IBD) and $\mathrm{CeD}$, implicating dysbiosis in disease pathogenesis [35-38]. Dysbiosis may affect autoimmunity by modulating the balance between commensal and pathogenic microorganisms and the host immune response, as discussed later.

In $\mathrm{CeD}$ the adaptive immune response is triggered by antigen-presenting cells (APC) that transport gluten peptides to $\mathrm{CD} 4^{+} \mathrm{T}$ cells, resulting in increased production and release of pro-inflammatory cytokines. In addition, increased production of metalloproteases and keratinocyte growth factor by stromal cells generate anti-gliadin and anti-tTG antibodies [39]. The response to gliadin is a Th1 driven process, while Th17 cytokines increase suggest that it also has a role in the development of CeD. Th17-mediated immune response is associated with alerted T-regulatory cell populations, which are also increased in active CeD. Th17 cells are regulated by the gut microbiota and also protect the host from infection, as well as other toxic molecules such as deaminated gliadin peptides [39]. 


\section{Dysbiosis in Celiac Disease:}

Approximately trillions of microorganisms inhabit our gut and contribute to normal bowel functions, including metabolic regulation and immune homeostasis [16-18,40]. The gut microbiota composition is established early in life and remains fairly constant throughout life in symbiotic tolerance with the host. Three bacterial phyla: Firmicutes, Bacteroides and Actinobacteria are the major components of the gut microbiota [41]. Dysbiosis is the imbalance of protective and pathogenic microbes in the host. It is typically caused by atypical microbial exposures, diet changes, antibiotic/medication use, and host genetics [40]. Initially, increased association of rod-shaped bacteria was reported in small bowel biopsies of active and inactive CeD patients [42]. Subsequently, in both stool cultures and duodenal biopsies reported an increased abundance of gram negative organisms, Bacteroides, Clostridium, E.Coli in CeD patients compared to healthy adults [43-45]. The concept of dysbiosis as risk factor for CeD was further strengthened by Swedish CeD epidemic study which also found higher numbers of rod-shaped bacteria (Clostridium spp., Prevotella spp., and Actinomyces spp.) in small bowel mucosa of CeD patients [46]. Since then there are several studies on fecal samples and duodenal mucosa using various techniques including 16SrRNA gene sequencing reporting similar results [47-50]. However, most of these studies are descriptive, some with patients on GFD or with gluten diet (GD) or symptomatic even on GFD. From these studies it is difficult to determine whether an altered gut microbiota is a cause or consequence of $\mathrm{CeD}$, as GD and GFD can also modulate gut microbiota. Overall most of the duodenal biopsies from $\mathrm{CeD}$ patients compared to healthy subjects showed dysbiosis and revealed an increased number of Gram-negative bacteria, Bacteroides, Firmicutes, E. Coli, Enterobacteriaceae, Staphylococcus, and a decrease in Bifidobacterium, Streptococcus, Provetella and Lactobacillus spp. The studies of fecal samples and duodenal biopsies in CeD patients on GFD versus GD and normal healthy population also showed an alteration of gut microbiota. CeD patients on GD showed an increase in Bacteroides-prevotella, Clostridium leptum, Histolitycum, Eubacterium, Atopobium and decrease in Bifidobacterium spp., B.longum, Lactobacillus spp., Leuconostoc, E. Coli and Staphylococcus compared to the normal population [50-54]. When $\mathrm{CeD}$ patients were treated with GFD, the increased microbial concentration was reduced to that in the normal population, thus suggesting that diet influenced gut microbiota. However, most studies showed only partial restoration of the microbiota when CeD patients were put on a GFD [47-49]. In addition, some of these patients were symptomatic for CeD even on GFD and showed relative abundance of Proteobacteria and decreased number of Firmicutes and Bacteroides suggesting dysbiosis as a cause of persistent GI symptoms even on GFD [55]. The precise reason for the inability of GFD to restore the microbiota similar to healthy subjects is not well understood, but it can be speculated that this may be due to individual genetics or prebiotic effect of GFD [55-57]. Although no cause or effect relationship can be deduced from these studies, the consensus is that dysbiosis may contribute to CeD. They further showed that patients with Dermatitis Herpeteformis (DH) also had a characteristic gut microbiota, with increased Firmicutes, Bacteriodes (Sterptococcus and Prevotella) suggesting that gut microbiota may play a role in disease manifestation [58].

To understand the biochemical mechanism of the effect of gut microbiota in $\mathrm{CeD}$, germ-free mice were colonized with bacteria from $\mathrm{CeD}$ and healthy subjects, respectively. In the germ-free mice, Lactobacillus, had a protective effect, while Pseudomonas aeruginosa was associated with CeD development [59]. P. aeruginosa was found to secrete LasB eleastase that altered intestinal barrier and facilitated translocation of gliadin peptides to the lamina propria where they activated the mucosal immune system. In contrast, Lactobacillus strains produced proteases that cleaved gluten into smaller peptides, which were less likely to be translocated to lamina propria, thus reduced their immunogenicity [59]. 


\section{Factors Modulating Gut Colonization in Celiac Disease:}

\subsection{Association with HLA-Haplotypes, Breast Feeding, Birth, Antibiotic Exposure}

There is a strong association between HLA-DQ2/8 haplotypes and CeD. Several investigators have examined this association with the gut microbiota. Infants with HLA-DQ2 and HLA-DQ8 and first-degree relatives with CeD have increased Firmicutes and Proteobacteria and less Actinobacteria and Bifidobacterium, suggesting that HLA genotype is associated with gut colonization by specific bacteria more prevalent in CeD patients and their relatives $[20,60]$. However, the HLA-DQ2/8 haplotype is also common in the general population, suggesting that genetics alone cannot explain the high prevalence of $\mathrm{CeD}$.

In HLA-DQ2/8 haplotype infants, the gut microbiota was further affected by feeding type, with breastfeeding having a protective effect against $\mathrm{CeD}$ [61-63]. Breastfed babies had higher Clostridium leptum, Bifidobacterium longum, and Bifidobacterium breve compared to formula fed babies, whose colon had higher counts of Bacteroides fragilis, Clostridium coccoides-Eubacterium rectale and E.coli. Breastfeeding has is thought to have a protective effect on the development of $\mathrm{CeD}$ but could not be confirmed in some studies [64]. The bacteria acquired during birth and first few months of life have a significant effect on commensal organisms in gut. The adult gut microbiome is typically established by two years of age [65].

Observational studies have also shown an increased prevalence of $\mathrm{CeD}$ in children born by elective cesarean section (CS), with a negative association with vaginal delivery, and also with premature rupture of membranes, most likely related to possible gut dysbiosis. Babies born vaginally predominantly acquire bacteria from maternal vaginal and perianal flora. The gut microbiota of vaginally delivered infants is similar to their mother vaginal microbiota compared to elective CS infants who have reduced microbial diversity and fewer Bifidobacterium species [66,67].

Antibiotic use in the first year of life was also associated with intestinal dysbiosis, reduced fecal microbial diversity, and early onset of $\mathrm{CeD}[68,69]$. Antibiotic-associated dysbiosis showed decreased numbers of Bifidobacterium longum and increased numbers of Bacteroides fragilis [70]. Moreover, Canova et al. demonstrated a dose-response relationship of antibiotic use with onset and risk of $\mathrm{CeD}$, specifically with increased Cephalosporin intake [71]. As already discussed, CeD was associated with decreased Bifidobacteria counts, lending support to the hypothesis that dysbiosis is risk factor for celiac disease [43,44].

Environmental triggers, especially food processing and additives are becoming increasingly recognized as contributing factors to the rising incidence of $\mathrm{CeD}$. Nanoparticles used in food processing, including metallic nanoparticles have antimicrobial activities. In vitro mouse model studies suggest an alteration in microbiota on exposure to these substances [72,73]. In mice, a dose dependent effect on the gut microbiome was noted with silver nanoparticles [74].

\subsection{Effect of Gut Microbiota/Dysbiosis on Processing of Gluten}

The effect on duodenal microbiota of the amount and timing of gluten introduction into the diet of an infant is controversial [75]. In small bowel partial digestion of gluten into peptides larger than ten amino acids are immunogenic, specifically 33-mer. Commensal microbiota, especially, Lactobacilli release peptidases that breakdown peptides and modify their immunogenic potential. P. aeruginosa is a pathogenic bacterium in patients with $\mathrm{CeD}$. Caminero et al. demonstrated that $P$. aeruginosa is capable of enhancing immunogenicity of 33-mer peptide, while Lactobacillus species isolated from the non-CeD controls decreased the immunogenicity of the peptides produced by P. aeruginosa [59]. Gluten can be metabolized by 144 strains of 35 bacterial species [25]. Most of these strains were from phyla Firmicutes and Actinobacteria, bacteria that protect CeD. Herran et al. isolated 31 strains of gluten-degrading bacteria from the human small intestine, of which 27 strains demonstrated peptidolytic activity towards the 33-mer peptide [76]. Lactobacilli were the most representative genera, suggesting a protective role for Lactobacillus in gluten digestion with decreasing the immunogenicity of 33-mer peptide. To grow 
effectively, Lactobacilli require high amounts of amino acids for their nitrogen source and energy metabolism. Lactobacilli and Bifidocbacterium spp. are believed to have a complex proteolytic and peptidolytic system, which may be involved in breakdown of gluten and its peptides and have the potential to be used as a probiotic supplement in CeD patients [77].

\subsection{Effect of Microbiota/Dysbiosis on the Intestinal Barrier in Celiac Disease}

Intestinal defense against pathogens includes physical barrier created by a mucous and tight junction complexes between neighboring epithelial cells. These tight junctions impede entry of pathogens and toxic molecules across the gut wall. Sustained inflammation or infection can lead to deregulation in the expression of adhesion molecules at tight junctions leading to entry of microbes and toxic/immunogenic substances in lamina propria. Of several proteins involved in tight junctions, disassembly of zonulin has been implicated in $\mathrm{CeD}$ patients [26,27]. In vitro studies showed that zonulin can be induced by both gluten peptides and enteric bacteria [78]. Zonulin release in vivo has also been reported to be affected by changes in gut microbiota composition [79]. Some studies suggested that the gliadin peptides bound to pro-inflammatory cytokine CXCR3 receptor on the intestinal epithelium released zonulin, thereby disrupting tight junctions and increasing epithelial permeability [26]. CXCL10, a ligand for CXCR 3 was also overexpressed in the small intestine of CeD patients. CXCL10/CXCR3 axis can be activated by pathogens and has been suggested to play a role in initiating gluten-induced inflammatory processes in the small bowel [26]. Germ-free rats with triggering factors such as Escherichia coli CBL2 or Shigella CBD8 had significantly reduced numbers of goblet cells in the small bowel and altered intestinal barrier and tight junctions. However, when given gliadin and IFN- $\gamma$ incubated with Bifidobacterium bifidum IATA-ES2, there was an increase in number of goblet cells, increased production of inhibitors of metalloproteinases and chemotactic agents, which provided a protective effect for the intestinal barrier [80]. Though these changes were established, it remains unclear if dysbiosis from $\mathrm{CeD}$ associated bacteria produced an inflammatory response to gluten or stimulated the mucosal inflammation response. Dysbiosis, through activation of the innate immune pathway may disrupt tight junctions/intestinal barrier and facilitate entry of incompletely digested gliadin peptides into the lamina propria. As discussed above, dysbiosis may also increase the amount and size of gliadin peptides due to differential peptidolytic activity of the gut microbiota.

\subsection{Effect of Gut Dysbiosis on Mucosal Immunity in Celiac Disease}

Microbiota colonization is necessary for the development and homeostasis of an optimal immune system. The gut microbial composition plays a role in regulation of the immune system. Alterations (dysbiosis or pathogenic organisms) may shift the immune response by favoring the development of certain subpopulation of lymphocytes that trigger a different cytokine response in the host. Physiologically the mucosal immune response to foreign antigens in the small intestine led to the development of tolerance to these antigens by apoptosis and active suppression by regulatory (Treg) $\mathrm{T}$ cells of antigen specific T cells $[18,81-84]$. As already discussed, there are similarities in activation of innate and adaptive immune system by immunogenic gliadin peptides and altered microbes in the gut. In patients with $\mathrm{CeD}$, loss of tolerance to gluten is associated with activation of gluten specific $\mathrm{CD} 4^{+} \mathrm{T}$ cells in the lamina propria and upregulation of IL-15, a pro inflammatory cytokine $[18,33,35,78-80]$. The gut microbiota also plays a role in maturation of dendritic cells, macrophages in the small bowel and causes variation in interactions of gliadin peptides with CD4+T cells. Pathogenic bacteria activate the innate immune system through activation of TLR. TLR-4 and CD14 complexes recognize bacterial endotoxins and lipopolysaccharide and active the innate immune system to release proinflammatory cytokines. Soluble CD14 is a serum marker for activation of the innate immune system that increased in patients with untreated $\mathrm{CeD}$, suggesting a role for dysbiosis in the pathogenesis of $\mathrm{CeD}$. Altered gut microbiota can also activate Th1, Th2 and Th17 mediated immune responses similar to upregulation by gliadin peptides $[33,85]$. CeD associated bacteria can increase IL-17A which may be directed against 
it [82]. Further work is needed to better characterize gut microbiota changes in $\mathrm{CeD}$, and their role in cytokine expression and clinical disease course.

These studies suggest that the gut microbiota affects gluten digestion, intestinal permeability, and the host immune system, all the mechanisms involved in pathogenesis of CeD. Although GFD can reduce the symptoms of $\mathrm{CeD}$ in most of the patients, however it does not completely restore the gut microbiota to that of healthy individuals [47-49]. Furthermore, dysbiosis was also observed in patients symptomatic on GFD. These studies suggest that gut dysbiosis contributes to the pathogenesis of $\mathrm{CeD}$ and utilization of probiotics may benefit $\mathrm{CeD}$ patients.

\section{Probiotics in Celiac Disease:}

Probiotics are live organisms, when ingested in adequate quantities provide a health benefit to the host [86]. They produce inhibitory substances that target pathogens, block their adhesion sites, compete for nutrients, prebiotics, degrade toxin receptors, and regulate immunity [87]. Dysbiosis, directly or indirectly contributes to $\mathrm{CeD}$, therefore probiotics modulate the microbial profile of the duodenum and increase the beneficial colonizing microbes influencing the $\mathrm{CeD}$ prognosis. Several in vitro and clinical trials have been conducted to assess the use of probiotics.

In vitro studies have demonstrated that select Lactobacilli strains when added to sourdough fermentation, lyse the proline/glutamine-rich gluten peptides, reduce the gluten concentration to $<10$ ppm (gluten-free), and decrease their immunotoxicity. Lactobacilli strains from pooled probiotic culture, during simulated gastrointestinal digestion, hydrolyzed proline-rich synthetic peptides involved in $\mathrm{CeD}$. Duodenal biopsies obtained from CeD patients following consumption of wheat bread produced with Lactobacilli showed no increase in IL2, IL-10, or IFN- levels compared to baseline [88]. Four strains of Lactobacilli (L. ruminis, L. Johndoni, L. amylovorus, L. salivaris) with highest gliadin peptide degrading activities reduced the immunotoxicity of gliadin peptides to induce $\mathrm{CeD}$, were identified from the upper gastrointestinal tract of pigs [89]. In a study that challenged $20 \mathrm{CeD}$ subjects to hydrolysed wheat gluten bread (containing Lactobacillus alimentaris, L. brevis, L. sanfranciscenis, L. Hilgardi) for six days, found no significant increase in IFN- $\gamma$ compared to healthy controls [90]. Encouraging results were also obtained with in vivo studies when $\mathrm{CeD}$ patients in remission were challenged for 60 days with Lactobacilli predigested gluten. There was no worsening of symptoms, intestinal permeability or serological markers suggesting that Lactobacilli derived endopeptidase was capable of completely degrading gluten and reducing its toxicity for $\mathrm{CeD}$ patients [91]. These studies support the addition of probiotics rich in Lactobacilli spp. either to mitigate the effect of accidental or contaminant gluten exposure or for added benefits imparted by GFD.

Dysbiosis in $\mathrm{CeD}$ is associated with abnormal tight junction and increased intestinal permeability that lead to increased translocation of gliadin peptides to lamina propria. The De Simone Formulation, a probiotic mixture of mostly Lactobacilli and Bifidobacteria, not only completely hydrolysed -gliadin-derived epitopes 62-75 and 33-mer peptide, but also improved epithelial barrier function by stabilizing tight junctions [92]. Lindfors et al. studied the effects of probiotics including strains Lactobacillus fermentum and B lactis on human colon Caco2 cells and showed that B. lactis decreased intestinal permeability in a dose dependent manner [93]. Furthermore, a mixture of gliadin peptides and Bifidobacteria downregulated proinflammatory cytokines production from Caco cells [94]. Mononuclear cells treated with B longum, B bifidum ES2 and then incubated with fecal samples from $\mathrm{CeD}$ patients found decreased proinflammatory cytokine production, suggesting that Bifodobacterial strains can reverse the effects of $\mathrm{CeD}$ associated bacteria [95].

Mouse models of $\mathrm{CeD}$ when challenged with gluten develops histological changes similar to $\mathrm{CeD}$ including intraepithelial lymphocytosis, villous atrophy, and crypt hyperplasia. These changes are associated with overexpression of CD71 (mediator of increased intestinal permeability), CD15, and IgA. When gluten digested with Saccharomyces boulardi KK1 strain, was fed to mice, there was a decrease in CD 71 expression, and local cytokine production and reversal of histological changes, supporting the beneficial effects of probiotics [96]. Lactobacillus rhamnosus GG strain also decreased gliadin peptide 
induced changes in intercellular junction proteins and gliadin induced enteropathy in Wistar rats sensitized with IFN-. Similar beneficial effects of probiotic B.longum CECT 7347 were noted in small bowel of weaning animals sensitized with IFN $\gamma$ and fed gliadin suggesting that early administration of probiotics may have a protective effect on bowel mucosa [97]. The effects of different Lactobacilli $s p$ on DQ8 transgenic mice showed modulation of innate and adaptive immune response [98,99]. They found that effects were strain specific. B longum NCC2705 strain produced a serine protease inhibitor (serpin) with immune modulating properties and prevented gliadin induced inflammation in genetically susceptible mouse model of $\mathrm{CeD}$ [98]. All these in vitro and animal studies demonstrated a beneficial effect of probiotics on digestion of gliadin peptides, intestinal barrier and immune system, which also showed beneficial effects on intestinal mucosa of mice [96-103]; Table 1.

Studies of the gut microbiota (fecal and duodenal biopsies) have revealed that Lactobacilli and Bifidobacteria reduce symptoms in $\mathrm{CeD}$ patients on a GFD, for a potential role either to mitigate the effect of accidental or contaminant gluten exposure $[44,45,104]$. These studies, along with in vitro and animal studies support the addition of probiotics to a GFD for beneficial or preventative effects. There are a few studies on the effect of probiotics in patients with $\mathrm{CeD}$ with cohorts ranging from 22-109 patients [105-114]. Most of these studies used Bifidobacterium strains, while a few studies used mixture of Lactobacilli spp. and Bifidobacterium spp. and one study used a probiotic preparation, the De Simone Formulation, made up of lactic acid and bifidobacteria (Tables 2 and 3). Most of these studies demonstrated modulation of gut microbiota, decreased inflammatory cytokines causing reduction in CeD symptoms. In a double-blind, randomized, placebo-controlled study of 33 newly diagnosed pediatric patients with CeD on a GFD, were given Bifidobacterium longum CECT $7347(n=18)$ for three months. A reduction was observed in the intestinal inflammation and decreased sIgA in fecal samples, compared to the placebo group. It also improved growth metrics, affected peripheral lymphocyte subsets, and decreased TNF [106]. In a double-blind randomized placebo-controlled study in untreated CeD patients on a GFD $(n=12), B$ infantis (Natren Life Start, NLS) treatment for three weeks improved gastrointestinal symptoms but had no effects on diarrhea, intestinal permeability or serum levels (tTG serology), cytokines or chemokines [105]. This may be due to the limited duration of study, selection of probiotic, dose or symptomatic patients with Marsh 3b-3c histology on biopsy. However, B infantis decreased Paneth cells in duodenal mucosa and -defensin (antimicrobial peptide) suggesting its effect on modulation of the innate immune system [110]. 
Table 1. Animal model studies to study the efficacy of probiotics in celiac disease.

\begin{tabular}{|c|c|c|c|c|c|}
\hline \multicolumn{2}{|c|}{ Probiotic } & \multirow[b]{2}{*}{ Study Design } & \multirow[b]{2}{*}{ Major Findings } & \multirow[b]{2}{*}{ Advantages of Probiotics } & \multirow[b]{2}{*}{ Reference } \\
\hline Composition-Strain(s) & $\begin{array}{l}\text { Duration of } \\
\text { Administration }\end{array}$ & & & & \\
\hline Lactobacillus casei ATCC 9595 & 21 days & $\begin{array}{l}\text { Transgenic mice expressing DQ-8 mucosally } \\
\text { immunized, challenged with intra-gastric gliadin }\end{array}$ & $\begin{array}{l}\text { Enhanced gliadin specific response } \\
\text { mediated by CD } 4^{+} \mathrm{T} \text { cells, gliadin } \\
\text { specific IFN } \gamma \text { expression, } \\
\text { pro-inflammatory polarisation of } \\
\text { cytokine milieu, no enteropathy } \\
\text { like mucosal response }\end{array}$ & $\begin{array}{l}\text { Inherent adjuvancy of } \\
\text { L.casei can be used to } \\
\text { enhance both mucosal and } \\
\text { T-cell mediated responses. }\end{array}$ & D'Arienzo et al. 2008. [101] \\
\hline Lactobacillus casei ATCC 9595 & 35 days & $\begin{array}{l}\text { Transgenic mice expressing } \mathrm{DQ}, \text {-mucosally } \\
\text { immunized, challenged with intra-gastric } \\
\text { chymotrypsin digested gliadin }\end{array}$ & $\begin{array}{l}\text { Complete recovery of villous } \\
\text { blunting, decreased weight loss, } \\
\text { recovered basal TNF- } \alpha \text { levels and } \\
\text { no change in CD25 } 5^{+} \text {cells and levels } \\
\text { of IL-2. }\end{array}$ & $\begin{array}{l}\text { L. casei was effective in } \\
\text { rescuing the normal } \\
\text { mucosal architecture and } \\
\text { Gut associated lymphoid } \\
\text { tissue homoeostasis in a } \\
\text { mouse model of gliadin } \\
\text {-induced enteropathy. }\end{array}$ & D. A'Arienzo et al. 2011 [102] \\
\hline $\begin{array}{l}\text { Saccharomyces boulardi } \mathrm{KK} 1 \\
\text { strain, hydrolysed the } 28-\mathrm{kDa} \\
\text { gliadin fraction }\end{array}$ & 30 days & $\begin{array}{l}\text { BALB/c mice -three generations fed with gluten free } \\
\text { diet to develop gluten sensitivity (G-), immunised } \\
\text { with } 50 \mu \mathrm{g} \text { whole gliadin emulsified in Freund's } \\
\text { adjuvant. The probiotic } S \text {. boullardi } \mathrm{KK} \text { strain or } \\
\text { control were administered orally for seven days and } \\
\text { then fed gluten diet for } 30 \text { days. Oral administration } \\
\text { of microbes continued twice per week. Intestine } \\
\text { samples collected one day after the last dose. }\end{array}$ & $\begin{array}{l}\text { The G+ mice developed villous } \\
\text { atrophy crypt hyperplasia, } \\
\text { and infiltration of T cells, } \\
\text { inflammation and over expression } \\
\text { of CD71. S. boulardi administration } \\
\text { improved enteropathy } \\
\text { development, decreased epithelial } \\
\text { cell expression of CD71 and } \\
\text { localized cytokine production. }\end{array}$ & $\begin{array}{l}\text { Anew mouse model for } \\
\text { human CD based on } \\
\text { histopathological features } \\
\text { and common biomarkers. } \\
\text { S. boulardi a probiotic to } \\
\text { treat CeD by reversing } \\
\text { disease development. }\end{array}$ & Papista et al. 2012 [96] \\
\hline $\begin{array}{l}\text { Lactobacillus rhamnosus GG } \\
\text { (L.GG) ATCC } 53103\end{array}$ & $\begin{array}{l}\text { Ten days after birth, L.GG } \\
\text { was administered for } \\
10 \text { days. }\end{array}$ & $\begin{array}{l}\text { Newborn Wistar rats divided into four groups, Ctrl } \\
\text { (without treatment); PTG (sensitized with } 1000 \text { U } \\
\text { IFN- } \gamma \text { intraperitoneally after birth and administered } \\
\text { gliadin for } 10 \text { days); L.GG treated with L.GG for } 10 \\
\text { days); Co-administered (sensitized and L.GG } \\
\text { together); Pre-treated (sensitized, then pre-treated } \\
\text { with gliadin and then administered with L.GG for } 10 \\
\text { days).After treatments the animals were sacrificed } \\
\text { and jejunal tissue samples were collected. }\end{array}$ & $\begin{array}{l}\text { Probiotic strain L.GG increased } \\
\text { expression of genes related to tight } \\
\text { junctions TJ) and adherin junctions } \\
\text { (AJ), after gliadin induced damage } \\
\text { and symptoms of CeD. }\end{array}$ & $\begin{array}{l}\text { Probiotic L.GG protects } \\
\text { rat intestinal mucosa } \\
\text { damage and can be } \\
\text { developed for the } \\
\text { therapeutic management } \\
\text { of gluten-related } \\
\text { disorders in humans. }\end{array}$ & Orlando et al. 2018 [100] \\
\hline
\end{tabular}


Table 2. Probiotics influence Celiac Disease development and treatment in adults.

\begin{tabular}{|c|c|c|c|c|c|c|}
\hline \multicolumn{2}{|c|}{ Probiotics } & \multicolumn{2}{|r|}{ Trial } & \multirow{2}{*}{ Outcome } & \multirow{2}{*}{ Conclusions } & \multirow{2}{*}{ Reference } \\
\hline Composition & Duration & Country & Participants/Design & & & \\
\hline $\begin{array}{l}\text { Bifido bacterium natren life } \\
\text { start (NLS) }\end{array}$ & $\begin{array}{l}\text { Three weeks-s2 } \\
\text { week run-in, three } \\
\text { weeks treatment, } \\
\text { and follow up on } \\
\text { day } 50\end{array}$ & Argentina & $\begin{array}{l}\text { Placebo controlled, double } \\
\text { blind study; } \\
22 \text { participants; } 12 \text { participants } \\
\text { received the probiotic capsule, } \\
10 \text { placebo. }\end{array}$ & $\begin{array}{l}\text { Effect of NLS on: (i) intestinal } \\
\text { permeability; } \\
\text { (ii) outcome of clinical } \\
\text { symptoms by GSRS } \\
\text { questionnaire; } \\
\text { (iii) modification of } \\
\text { immunologic indicators } \\
\text { influenced by gluten. }\end{array}$ & $\begin{array}{l}\text { Administration of NLS to untreated CeD } \\
\text { patients does not modify protein } \\
\text { abnormalities but might improve symptoms } \\
\text { and produced some immunologic changes. } \\
\text { Participant pool was small, more trials } \\
\text { are needed. }\end{array}$ & Smecuol et al. 2013 [105] \\
\hline $\begin{array}{l}\text { A proprietary blend of } 450 \\
\text { billion viable lyophilized } \\
\text { bacteria ( } 9 \text { strains) known as } \\
\text { the De Simone formulation, } \\
\text { previously VSL\#3. }\end{array}$ & 12 weeks study & Australia & $\begin{array}{l}47 \text { enrolments, final results } \\
\text { were for } 42 \text { participants; } \\
\text { equally divided in the active } \\
\text { group that received the } \\
\text { probiotics and } 21 \text { in the placebo } \\
\text { group. }\end{array}$ & $\begin{array}{l}\text { Primary outcome: microbial } \\
\text { counts of and comparison } \\
\text { between baseline and end of } \\
\text { study of predominant, } \\
\text { pathogenic and } \\
\text { opportunistic bacteria. } \\
\text { Secondary efficacy outcomes: } \\
\text { urinary metabolomics and } \\
\text { faecal lactoferrin }\end{array}$ & $\begin{array}{l}\text { No significant change in the gastrointestinal } \\
\text { microbial counts in CeD individuals with } \\
\text { persistent symptoms over } 12 \text { weeks period. } \\
\text { Future studies to increase the dosage of } \\
\text { VSL\#3 and duration of treatment. }\end{array}$ & Harnett et al. 2016 [109] \\
\hline $\begin{array}{l}\text { Yogurt with probiotic from } \\
\text { PIA, Nova Petropolis-RS } \\
\text { (undetermined microbial } \\
\text { concentration) }\end{array}$ & 30 days & Brazil & $\begin{array}{l}17 \text { healthy and } 14 \text { participants } \\
\text { with celiac disease }\end{array}$ & $\begin{array}{l}\text { Faecal bifidobacteria } \\
\text { concentration after consuming } \\
100 \mathrm{~g} \text { of yogurt in the morning. }\end{array}$ & $\begin{array}{l}\text { Faecal bifidobacteria was higher in healthy } \\
\text { patients compared to CeD patients. } \\
\text { Probiotic yogurt consumption increased the } \\
\text { bifidobacteria number in CeD patients, but } \\
\text { could not reach the concentration in } \\
\text { healthy participants. }\end{array}$ & Martinello et al. 2017 [113] \\
\hline $\begin{array}{l}\text { Bifidobacterium infantis Natren } \\
\text { Life Start super strain } \\
\text { (NLS-SS) }\end{array}$ & Six weeks & Argentina & $\begin{array}{l}41 \text { participants, in three groups: } \\
\text { (i) } n=24, \mathrm{CeD} \text { active, no } \\
\text { treatment; } \\
\text { (ii) } n=12, \mathrm{CeD} \text { active with NLS; } \\
\text { (iii) } n=5 ; \mathrm{CeD} 1 \text { year GFD }\end{array}$ & $\begin{array}{l}\text { Determine mucosal expression } \\
\text { of innate immune markers: } \\
\text { number of macrophages, } \\
\text { Pancth cells and } \alpha \text {-defensin- } 5 \\
\text { expression by } \\
\text { immunohistochemistry in } \\
\text { duodenal biopsies. }\end{array}$ & $\begin{array}{l}\text { Duodenal biopsies revealed that } B \text {. infantis } \\
\text { decreased all the three markers, macrophage } \\
\text { counts, Pancth cell counts and } \alpha \text {-defensin- } 5 \\
\text { in CeD patients. However, the decrease in } \\
\text { macrophage counts was higher in gluten } \\
\text { free diets. } \\
\text { Future studies are needed to study methods } \\
\text { to obtain synergistic effect of GFD and } \\
\text { Binfantis supplementation. }\end{array}$ & Pinto-Sanchez et al. 2017 [110] \\
\hline $\begin{array}{l}\text { A product containing five } \\
\text { strains: Lactobacillus casei, } \\
\text { Lactobacillus plantarum, } \\
\text { Bifidobacterium animalis subsp. } \\
\text { Lacti, B. breve Bbr8 LMG } \\
\text { P-17501 and B. breve B110 } \\
\text { LMG P-17500. }\end{array}$ & $\begin{array}{l}\text { A six-week treatment } \\
\text { period, precede by } \\
\text { 2-week run in period } \\
\text { followed by a } 6 \text { week } \\
\text { follow up phase for a } \\
\text { total of } 14 \text { weeks. }\end{array}$ & Italy & $\begin{array}{l}\text { Prospective, double- blind, } \\
\text { randomized placebo-controlled } \\
\text { parallel group study. } 109 \\
\text { participants were included in } \\
\text { the study. } 54 \text { in the probiotic } \\
\text { and } 55 \text { in the placebo group. }\end{array}$ & $\begin{array}{l}\text { Primary outcome to determine } \\
\text { if probiotics improve GI } \\
\text { symptoms as assessed by } \\
\text { Irritable Bowel syndrome } \\
\text { severity scoring system } \\
\text { (IBS-SSS). } \\
\text { Five secondary outcomes } \\
\text { including modification in gut } \\
\text { microbiota and metabolic } \\
\text { fecal profile. }\end{array}$ & $\begin{array}{l}\text { Probiotics significantly decreased the } \\
\text { IBS-SSS and GSRS scores compared to the } \\
\text { placebo. Presumptivr lactic acidbacteria, } \\
\text { Staphylococus and Bifidobacterium counts } \\
\text { were also higher with probiotic treatment } \\
\text { compared to the placebo group. Six-week } \\
\text { Probiotic treatment was effective in } \\
\text { managing IBS-type symptoms. Probiotics in } \\
\text { CeD patients on strict GFD diet modified } \\
\text { the gut microbiota positively by increasing } \\
\text { the Bifidobacteria. }\end{array}$ & Francavilla et al. 2019 [112] \\
\hline
\end{tabular}


Table 3. Probiotics influence Celiac Disease development and treatment in children.

\begin{tabular}{|c|c|c|c|c|c|c|}
\hline \multicolumn{2}{|c|}{ Probiotics } & \multicolumn{2}{|r|}{ Trial } & \multirow{2}{*}{ Outcome } & \multirow{2}{*}{ Conclusions } & \multirow{2}{*}{ Reference } \\
\hline Composition & Duration & Country & Participants/Design & & & \\
\hline $\begin{array}{l}\text { Bifidobacterium longum } \\
\text { CECT } 7347\end{array}$ & 3 months & Spain & $\begin{array}{l}33 \text { participants in a double blind, } \\
\text { randomized, } \\
\text { placebo-controlled trial. }\end{array}$ & $\begin{array}{l}\text { Baseline and post-intervention } \\
\text { outcomes included immune } \\
\text { phenotype of peripheral blood } \\
\text { cells, serum cytokine } \\
\text { concentration, fecal secretory } \\
\text { IgA content, anthropometric } \\
\text { parameters and intestinal } \\
\text { microbiota composition. }\end{array}$ & $\begin{array}{l}\text { Probiotic treatment showed greater height } \\
\text { percentile, decreased peripheral CD } 3^{+} \mathrm{T} \\
\text { lymphocytes, and slightly reduced TNF- } \alpha \\
\text { concentration. The number of Bacteroides } \\
\text { fragilis and content of secretory IgA in the } \\
\text { stool was also reduced by the probiotic } \\
\text { treatment. The small sample size is a } \\
\text { limitation of the study. }\end{array}$ & Olivares et al. 2014 [106] \\
\hline $\begin{array}{l}\text { Bifidobacterium breve } \mathrm{BRO} 3 \\
\text { and B. breve } \mathrm{B} 632\end{array}$ & Three months & Slovenia & $\begin{array}{l}\text { Double blind placebo-controlled } \\
\text { trial with } 49 \text { participants } \\
\text { randomized into two groups: First } \\
\text { group of } 24 \text { received the probiotic } \\
\text { and the second group of } 25 \\
\text { received the placebo. } 18 \text { healthy } \\
\text { children were included as controls. }\end{array}$ & $\begin{array}{l}\text { Outcomes: Serum production } \\
\text { of interleukin } 10 \text { (IL-10); tumor } \\
\text { necrosis factor alpha (TNF- } \alpha \text { ). }\end{array}$ & $\begin{array}{l}\text { TNF- } \alpha \text { levels decreased after } 3 \text { months of } \\
\text { probiotic treatment, however on follow up } \\
\text { after } 3 \text { months, the levels increased. The } \\
\text { IL-10 levels were below detection. }\end{array}$ & Klemenak et al. 2015 [107] \\
\hline $\begin{array}{l}\text { Bifidbacterium breve strains } \\
\text { B632 and BRO3 }\end{array}$ & 3 months & Slovenia & $\begin{array}{l}\text { Double-blinded, } \\
\text { placebo-controlled study with } 40 \\
\text { CeD patients and } 16 \text { healthy } \\
\text { children. The CeD patients were in } \\
\text { teo groups of } 20 \text { each, with one } \\
\text { receiving the probiotic and the } \\
\text { other placebo. }\end{array}$ & $\begin{array}{l}\text { Determination of microbiome } \\
\text { after probiotic treatment. }\end{array}$ & $\begin{array}{l}\text { Probiotic treatment increased the Firmicutes } \\
\text { and restored the physiological } \\
\text { Firmicute/Bacteriodetes ratio. Three-month } \\
\text { administration of probiotic can restore the } \\
\text { microbiota of CeD patients similar to } \\
\text { healthy children. }\end{array}$ & $\begin{array}{l}\text { Quagliariello et al. } \\
2016 \text { [108] }\end{array}$ \\
\hline $\begin{array}{l}\text { Bifidbacterium breve strains } \\
\text { B632 and BRO3 }\end{array}$ & 3 months & Slovenia & $\begin{array}{l}\text { Double-blinded, } \\
\text { placebo-controlled study with } 40 \\
\text { CeD patients and } 16 \text { healthy } \\
\text { children. The CeD patients were in } \\
\text { teo groups of } 20 \text { each, with one } \\
\text { receiving the probiotic and the } \\
\text { other placebo. }\end{array}$ & $\begin{array}{l}\text { To study the influence of } \\
\text { probiotics on the fecal } \\
\text { microbiome, Short chain fatty } \\
\text { acids (SCFA) and serum } \\
\text { TNF- } \alpha \text {. }\end{array}$ & $\begin{array}{l}\text { Verrucomicrobia, Paracubacteria and some yet } \\
\text { unknown phyla of bacteria and archaea } \\
\text { showed a strong correlation to CeD. These } \\
\text { new microbiota may have a role in CeD. }\end{array}$ & Primec et al. 2019 [111] \\
\hline $\begin{array}{l}\text { Lactobacillus reuteri; } \\
\text { Lactobacillus rhamnosus and } \\
\text { some unidentified }\end{array}$ & $\begin{array}{l}\text { USA, Finland, } \\
\text { Germany and Sweden }\end{array}$ & Different time periods & $\begin{array}{l}\text { A prospective study using a cohort } \\
\text { of } 6520 \text { genetically susceptible } \\
\text { children. } 1460 \text { children were } \\
\text { reported probiotic use in the first } \\
\text { year of life. }\end{array}$ & $\begin{array}{l}\text { To study the association } \\
\text { between the exposure of } \\
\text { probiotics via dietary } \\
\text { supplements or by infant } \\
\text { formula by the age } 1 \text { year to the } \\
\text { development of celiac disease } \\
\text { autoimmunity (CDA) or CeD. }\end{array}$ & $\begin{array}{l}\text { Overall exposure of probiotics during the } \\
\text { first year of age was not associated with } \\
\text { CDA or CeD. However, intake of probiotics } \\
\text { via dietary supplements was associated } \\
\text { with increased risk of CDA. }\end{array}$ & Uusitalo et al. 2019 [114] \\
\hline
\end{tabular}


Bifidobacterium breve BR03 and B63 given for three months reduced TNF production in children on a GFD suggesting an inhibitory effect on the innate immune system. However, the effect was lost three months after completing the study [107]. Using the same probiotic with a GFD in CeD adult patients, Primec et al. also showed a decrease in TNF- $\alpha$, increase in Fermicutes spp. and decrease in Verrucomicrobia as well as new phyla [111]. TNF- $\alpha$, an important mediator in activation of immune system has a direct and indirect effect on mucosal damage in $\mathrm{CeD}$. Decreased cytokine production by probiotics along with GFD may have beneficial effect. These results need to be confirmed with larger prospective studies using appropriate dose and mix of probiotics. To study the effects of multispecies probiotics on irritable bowel syndrome (IBS-) type symptoms, Francavilla et al. enrolled 109 patients symptomatic $\mathrm{CeD}$ patients on GFD. Six weeks of treatment with probiotic showed decrease in severity of IBS-like symptoms compared to placebo treatment. This was associated with increase in anaerobes, Bifidobacterium, Actinobacteria in fecal samples [112].

In addition to endopeptidase abilities, probiotics can also alter the host immune function. Saccharomyces boulardii blocks toxin receptors, while Bifidobacterium and Lactobacillus strains secrete short chain volatile fatty acids, hydrogen peroxide, and antibacterial peptides (Lactocidin, Acidophilin, and Lactacin B). By reducing intraluminal $\mathrm{pH}$, pathogenic bacteria were reduced. Furthermore, promoting epithelial growth factor (EGF) enhanced barrier function [115]. Certain strains, such as Lactbacilli, GG, B. lactis, and Saccharomyces boulardii regulate humoral modulation through expression of TGF, IL-10, and IL-6, which subsequently promote B-cell maturation in favor of IgA secretion.

There is a paucity of studies in probiotics in humans, and thus difficult to determine their role in the management of $\mathrm{CeD}[1,34,116-119]$. In addition, the studies cannot conclusively demonstrate that probiotics improved gut barrier function, likely due to short duration or inadequate dose or strain, or their inability to modulate the gut microbiota. Further work is needed to better understand the role of probiotics in CeD.

\section{Summary}

Probiotics can influence the CeD by three potential mechanisms. The first is to digest the gluten proteins to non-immunogenic small polypeptides, eliminating and/or reducing the trigger for $\mathrm{CeD}$, thus preventing its onset. The second is to maintain the intestinal barrier by preventing the access of immunogenic polypeptides to lamina propria. The third and most interesting is the role of probiotics in the homeostasis of the gut microbiome and regulation of both the innate and adaptive immune systems. Though alterations in the gut microbiota/dysbiosis are associated with the development of $\mathrm{CeD}$, its exact function in pathogenesis remains unclear. The limited number of human studies show the positive effects of probiotics as a therapeutic modality in $\mathrm{CeD}$, but more studies are needed specifically to modulate the gut microbiome to alter the disease course. To-date probiotics are unable to provide a durable modification of gut microbiota, and duodenal dysbiosis persisted. There are also concerns regarding safety of probiotics, including documented bacteria, lack of regulation, and lack of knowledge regarding interactions with the host microbiota [119]. There appears to be a role for probiotics to modulate the gut microbiota in $\mathrm{CeD}$, however, further randomized studies, especially in humans, are needed to better understand its role in treating $\mathrm{CeD}$. A basic understanding of the biochemical/molecular mechanism by which probiotics influence $\mathrm{CeD}$ will help to precisely formulate type and concentration of beneficial microbes to develop a safe therapeutic modality to alter the CeD course.

Author Contributions: L.A.D. and R.C. conceived the review topics. R.C. prepared the first draft. L.A.D. reviewed and edited the draft. R.C. and L.A.D. read and finalized the manuscript.

Funding: This research received no external funding.

Conflicts of Interest: The authors declare no conflict of interest. 


\section{References}

1. Ludvigsson, J.F.; Leffler, D.A.; Bai, J.C.; Biagi, F.; Fasano, A.; Green, P.H.; Hadjivassiliou, M.; Kaukinen, K.; Kelly, C.P.; Leonard, J.N.; et al. The Oslo definitions for coeliac disease and related terms. Gut 2013, 62, 43-52. [CrossRef] [PubMed]

2. Fasano, A.; Catassi, C. Celiac Disease. N. Engl. J. Med. 2012, 367, 2419-2426. [CrossRef] [PubMed]

3. Kelly, C.P.; Bai, J.C.; Liu, E.; Leffler, D.A. Celiac disease: Clinical spectrum and management. Gastroenterology 2015, 148, 1175-1186. [CrossRef] [PubMed]

4. Caio, G.; Volta, U.; Sapone, A.; Leffler, D.A.; De Giorgio, R.; Catassi, C.; Fasano, A. Celiac Disease: A comprehensive current review. BMC Med. 2019, 17, 142. [CrossRef] [PubMed]

5. Singh, P.; Arora, A.; Strand, T.A.; Leffler, D.A.; Mäki, M.; Kelly, C.P.; Ahuja, V.; Makharia, G.K. Global prevalence of celiac disease: Systematic review and meta-analysis. Clin. Gastroenterol. Hepatol. 2018, 16, 823-836. [CrossRef] [PubMed]

6. Kang, J.Y.; Kang, A.H.; Green, A.; Gwee, K.A.; Ho, K.Y. Systematic review: Worldwide variation in the frequency of coeliac disease and changes over time. Aliment. Pharmacol. Ther. 2013, 38, 226-245. [CrossRef]

7. Makharia, G.K.; Catassi, C. Celiac Disease in Asia. Gastroenterol. Clin. North Am. 2019, 48, 101-113. [CrossRef]

8. Rubio-Tapia, A.; Ludvigsson, J.F.; Brantner, T.L.; Murray, J.A.; Everhart, J.E. The prevalence of celiac disease in the United States. Am. J. Gastroenterol. 2012, 107, 1538-1544. [CrossRef]

9. Burger, J.P.; Roovers, E.A.; Drenth, J.P.; Meijer, J.W.; Wahab, P.J. Rising incidence of celiac disease in the Netherlands; an analysis of temporal trends from 1995-2010. Scan. J. Gastroenterol. 2014, 49, $933-941$. [CrossRef]

10. Liu, E.; Lee, H.S.; Arnosson, C.A.; Hagopian, W.A.; Koletzko, S.; Rewers, M.J.; Eisenbarth, G.S.; Bingley, P.J.; Bonifacio, E.; Simell, V.; et al. Pediatric celiac disease according to HLA haplotype and country. N. Engl. J. Med. 2014, 371, 42-49. [CrossRef]

11. Trynka, G.; Wijmenga, C.; van Heel, D.A. A genetic perspective on coeliac disease. Trends Mol. Med. 2010, 6, 537-550. [CrossRef] [PubMed]

12. De Hass, E.C.; Kumar, V.; Wijmenga, C. Immunogenetics of celiac disease. In Clinical Gastroenterology; Devi, S., Mullin, G.E., Eds.; Humana Press: Totowa, NJ, USA, 2013; pp. 1-16.

13. Withoff, S.; Li, X.; Jonkers, I.; Wijmenga, C. Understanding celiac disease by genomics. Trends Genet. 2016, 32, 295-308. [CrossRef] [PubMed]

14. Galipeau, H.J.; Verdu, E.F. Gut microbes and adverse food reactions: Focus on gluten related disorders. Gut Microbes 2014, 5, 594-605. [CrossRef] [PubMed]

15. Verdu, E.F.; Galipeau, H.J.; Jabri, B. Novel players in coeliac disease pathogenesis: Role of the gut microbiota. Nat. Rev. Gastroenterol. Hepatol. 2015, 2, 497-506. [CrossRef] [PubMed]

16. Hills, R.D., Jr.; Pontefract, B.A.; Mishcon, H.R.; Black, C.A.; Sutton, S.C.; Theberge, C.R. Gut Microbiome: Profound Implications for Diet and Disease. Nutrients 2019, 11, 1613. [CrossRef]

17. Jandhyala, S.M.; Talukdar, R.; Subramanyam, C.; Vuyyuru, H.; Sasikala, M.; Nageshwar Reddy, D. Role of the normal gut microbiota. World J. Gastroenterol. 2015, 21, 8787-8803. [CrossRef]

18. Kho, Z.Y.; Lal, S.K. The human gut microbiome-A potential controller of wellness and disease. Front. Microbiol. 2018, 9, 1835. [CrossRef]

19. Schirmer, M.; Garner, A.; Lamakis, H. Microbial genes and pathways in inflammatory bowel disease. Nat. Rev. Microbiol. 2019, 17, 497-511. [CrossRef]

20. Olivares, M.; Neef, A.; Castillejo, G.; Palma, G.D.; Varea, V.; Capilla, A.; Palau, F.; Nova, E.; Marcos, A.; Polanco, I.; et al. The HLA-DQ2 genotype selects for early intestinal microbiota composition in infants at high risk of developing coeliac disease. Gut 2015, 64, 406-417. [CrossRef]

21. Shan, L.; Molberg, O.; Parrot, I.; Hausch, F.; Filiz, F.; Gray, G.M.; Sollid, L.M.; Khosla, C. Structural basis for gluten intolerance in celiac sprue. Science 2002, 297, 2275-2279. [CrossRef]

22. Shan, L.; Qiao, S.W.; Arentz-Hansen, H.; Molberg, O.; Gray, G.M.; Sollid, L.M.; Khosla, C. Identification and analysis of multivalent proteolytically resistant peptides from Gluten: Implications for celiac sprue. J. Proteome Res. 2005, 4, 1732-1741. [CrossRef] [PubMed]

23. Sollid, L.M.; Qiao, S.W.; Anderson, R.P.; Gianfrani, C.; Koning, F. Nomenclature and listing of celiac disease relevant gluten T-cell epitopes restricted by HLA-DQ molecules. Immunogenetics 2012, 64, 455-460. [CrossRef] [PubMed] 
24. Gutierrez, S.; Perez-Andrés, J.; Martínez-Blanco, H.; Ferrero, M.A.; Vaquero, L.; Vivas, S.; Casqueiro, J.; Rodríguez-Aparicio, L.B. The human digestive tract has proteases capable of gluten hydrolysis. Mol. Metab. 2017, 6, 693-703. [CrossRef] [PubMed]

25. Caminero, A.; Herran, A.R.; Nistal, A.; Pérez-Andrés, J.; Vaquero, L.; Vivas, S.; Ruiz de Morales, J.M.; Albillos, S.M.; Casqueiro, J. Diversity of the cultivable human gut microbiome involved in gluten metabolism: Isolation of microorganisms with potential interest for coeliac disease. FEMS Microbiol. Ecol. 2014, 88, 309-319. [CrossRef]

26. Heyman, M.; Abed, J.; Lebreton, C.; Cerf-Bensussan, N. Intestinal permeability in coeliac disease: Insight into mechanisms and relevance to pathogenesis. Gut 2012, 61, 1355-1364. [CrossRef]

27. Lammers, K.M.; Lu, R.; Brownley, J.; Lu, B.; Gerard, C.; Thomas, K.; Rallabhandi, P.; Shea-Donohue, T.; Tamiz, A.; Alkan, S.; et al. Gliadin induces an Increase in intestinal permeability and Zonulin release by binding to the chemokine receptor CXCR3. Gastroenterology 2008, 135, 194-204. [CrossRef]

28. Menard, S.; Leberton, C.; Schumann, M.; Matysiak-Budnik, T.; Dugave, C.; Bouhnik, Y.; Malamut, G.; Cellier, C.; Allez, M.; Crenn, P.; et al. Paracellular versus transcellular intestinal permeability to gliadin peptides in active celiac disease. Am. J. Pathol. 2012, 180, 608-615. [CrossRef]

29. Leberton, C.; Menard, S.; Abed, J. Interactions among secretory immunoglobulin A, CD71, and transglutaminase-2 affect permeability of intestinal epithelial cells to gliadin peptides. Gastroenterology 2012, 143, 698-707. [CrossRef]

30. Gianfrani, C.; Auricchio, S.; Troncone, R. Adaptive and innate immune responses in celiac disease. Immunol. Lett. 2005, 99, 141-145. [CrossRef]

31. Hardy, M.Y.; Tye-Din, J.A. Coeliac disease: A unique model for investigating broken tolerance in autoimmunity. Clin. Transl. Immunol. 2016, 5, e112. [CrossRef]

32. Dubois, P.C.; Trynka, G.; Franke, L.; Hunt, K.A.; Romanos, J.; Curtotti, A.; Zhernakova, A.; Heap, G.A.; Adány, R.; Aromaa, A.; et al. Multiple common variants for celiac disease influencing immune gene expression. Nat. Genet. 2010, 42, 295-302. [CrossRef] [PubMed]

33. Sjoberg, V.; Sandstro, O.; Hedberg, M.; Hammarström, S.; Hernell, O.; Hammarström, M.L. Intestinal T-cell Responses in Celiac Disease-Impact of Celiac Disease. PLoS ONE 2013, 8, e53414. [CrossRef] [PubMed]

34. Serena, G.; Kelly, C.P.; Fasano, A. Nondietary therapies for celiac disease. Gastroenterol. Clin. North Am. 2019, 48, 145-163. [CrossRef] [PubMed]

35. Marasco, G.; Di Biase, A.R.; Schiumerini, R.; Eusebi, L.H.; Iughetti, L.; Ravaioli, F.; Scaioli, E.; Colecchia, A.; Festi, D. Gut microbiota and celiac disease. Dig. Dis. Sci. 2016, 61, 1461-1472. [CrossRef] [PubMed]

36. Iversen, R.; Roy, B.; Stamnaes, J.; Høydahl, L.S.; Hnida, K.; Neumann, R.S.; Korponay-Szabó, I.R.; Lundin, K.E.A.; Sollid, L.M. Efficient T cell-B cell collaboration guides autoantibody epitope bias and onset of celiac disease. Proc. Natl. Acad. Sci. USA 2019, 116, 15134-15139. [CrossRef] [PubMed]

37. Kalliomaki, M.; Satokari, R.; Lahteenoja, H.; Vähämiko, S.; Grönlund, J.; Routi, T.; Salminen, S. Expression of microbiota, Toll-like receptors, and their regulators in the small intestinal mucosa in celiac disease. J. Pediatr. Gastroenterol. Nutr. 2012, 54, 727-734. [CrossRef]

38. Herrera, M.G.; Pizzuto, M.; Lonez, C.; Rott, K.; Hütten, A.; Sewald, N.; Ruysschaert, J.M.; Dodero, V.I. Large supramolecular structures of 33-mer gliadin peptide activate Toll-like receptors in macrophages. Nanomedicine 2018, 14, 1417-1427. [CrossRef]

39. Fernandez, S.; Molina, I.J.; Romero, P.; González, R.; Peña, J.; Sánchez, F.; Reynoso, F.R.; Pérez-Navero, J.L.; Estevez, O.; Ortega, C.; et al. Characterization of Gliadin-specific Th17 cells from the mucosa of celiac disease patients. Am. J. Gastroenterol. 2011, 106, 528-538. [CrossRef]

40. Krishnareddy, S. The microbiota in celiac disease. Gastroenterol. Clin. North Am. 2019, 48, 115-126. [CrossRef]

41. Tap, J.; Mondot, S.; Levenez, F.; Pelletier, E.; Caron, C.; Furet, J.P.; Ugarte, E.; Muñoz-Tamayo, R.; Paslier, D.L.; Nalin, R.; et al. Towards the human intestinal microbiota phylogenetic core. Environ. Microbiol. 2009, 11, 2574-2584. [CrossRef]

42. Forsberg, G.; Fahlgren, A.; Horstedt, P.; Hammarström, S.; Hernell, O.; Hammarström, M.L. Presence of bacteria and innate immunity of intestinal epithelium in childhood celiac disease. Am. J. Gastroenterol. 2004, 99, 894-904. [CrossRef] [PubMed]

43. Collado, M.C.; Donat, E.; Ribes-Koninckx, C.; Calabuig, M.; Sanz, Y. Specific duodenal and faecal bacteria groups associated with paediatric coeliac disease. J. Clin. Pathol. 2009, 62, 264-269. [CrossRef] [PubMed] 
44. De Palma, G.; Nadal, I.; Medina, M.; Donat, E.; Ribes-Koninckx, C.; Calabuig, M.; Sanz, Y. Intestinal dysbiosis and reduced immunoglobulin-coated bacteria associated with coeliac disease in children. BMC Microbiol. 2010, 10, 63. [CrossRef] [PubMed]

45. Nadal, I.; Donat, E.; Ribes-Koninckx, C.; Calabuig, M.; Sanz, Y. Imbalance in the composition of the duodenal microbiota of children with coeliac disease. J. Med. Microbiol. 2007, 56, 1669-1674. [CrossRef] [PubMed]

46. Ou, G.; Hedberg, M.; Horstedt, P.; Baranov, V.; Forsberg, G.; Drobni, M.; Sandström, O.; Wai, S.N.; Johansson, I.; Hammarström, M.L.; et al. Proximal small intestinal microbiota and identification of rod-shaped bacteria associated with childhood celiac disease. Am. J. Gastroenterol. 2009, 104, 3058-3067. [CrossRef] [PubMed]

47. Bascunan, K.; Araya, M.; Roncoroni, M.; Doneda, L.; Elli, L. Dietary gluten as a conditioning factor of the gut microbiota in celiac disease. Adv. Nutr. 2019. [CrossRef]

48. Caminero, A.; McCarville, J.L.; Galipeau, H.J.; Deraison, C.; Bernier, S.P.; Constante, M.; Rolland, C.; Meisel, M.; Murray, J.A.; Yu, X.B.; et al. Duodenal bacterial proteolytic activity determines sensitivity to dietary antigen through protease activated receptor-2. Nat. Commun. 2019, 10, 1198. [CrossRef]

49. Bonder, M.J.; Tigchelaar, E.F.; Cai, X.; Trynka, G.; Cenit, M.C.; Hrdlickova, B.; Zhong, H.; Vatanen, T.; Gevers, D.; Wijmenga, C.; et al. The influence of a short-term gluten-free diet on the human gut microbiome. Genome Med. 2016, 8, 45. [CrossRef]

50. Di Cagno, R.; De Angelis, M.; De Pasquale, I.; Ndagijimana, M.; Vernocchi, P.; Ricciuti, P.; Gagliardi, F.; Laghi, L.; Crecchio, C.; Guerzoni, M.E.; et al. Duodenal and faecal microbiota of celiac children: Molecular, phenotype and metabolome characterization. BMC Microbiol. 2011, 11, 219. [CrossRef]

51. Nistal, E.; Caminero, A.; Herran, A.R.; Arias, L.; Vivas, S.; de Morales, J.M.; Calleja, S.; de Miera, L.E.; Arroyo, P.; Casqueiro, J. Differences of small intestinal bacteria populations in adults and children with/without celiac disease: Effect of age, gluten diet, and disease. Inflamm. Bowel Dis. 2012, 18, 649-656. [CrossRef]

52. Bodkhe, R.; Shetty, S.A.; Dhotre, D.P.; Verma, A.K.; Bhatia, K.; Mishra, A.; Kaur, G.; Pande, P.; Bangarusamy, D.K.; Santosh, B.P.; et al. Comparison of small gut and whole gut microbiota of first degree relatives with adult celiac disease patients and controls. Front. Microbiol. 2019, 10, 164. [CrossRef] [PubMed]

53. Nistal, E.; Caminero, A.; Vivas, S.; Ruiz de Morales, J.M.; Sáenz de Miera, L.E.; Rodríguez-Aparicio, L.B.; Casqueiro, J. Differences in faecal bacteria populations and faecal bacteria metabolism in healthy adults and celiac disease patients. Biochimie 2012, 94, 1724-1729. [CrossRef]

54. Golfetto, L.; de Senna, F.D.; Hermes, J.; Beserra, B.T.; França Fda, S.; Martinello, F. Lower bifidobacteria counts in adult patients with celiac disease on a gluten-free diet. Arq. Gastroenterol. 2014, 51, 139-143. [CrossRef] [PubMed]

55. Wacklin, P.; Laurikka, P.; Lindfors, K.; Collin, P.; Salmi, T.; Lähdeaho, M.L.; Saavalainen, P.; Mäki, M.; Mättö, J.; Kurppa, K.; et al. Altered duodenal microbiota composition in celiac disease patients suffering from persistent symptoms on a long-term gluten-free diet. Am. J. Gastroenterol. 2014, 109, 1933-1941. [CrossRef] [PubMed]

56. Tjellstrom, B.; Stenhammar, L.; Hogberg, L.; Fälth-Magnusson, K.; Magnusson, K.E.; Midtvedt, T.; Sundqvist, T.; Norin, E. Gut microflora associated characteristics in children with celiac disease. Am. J. Gastroenterol. 2005, 100, 2784-2788. [CrossRef] [PubMed]

57. De Meij, T.G.J.; Budding, A.E.; Grasman, M.E.; Kneepkens, C.M.; Savelkoul, P.H.; Mearin, M.L. Composition and diversity of the duodenal mucosa-associated microbiome in children with untreated coeliac disease. Scand. J. Gastroenterol. 2013, 48, 530-536. [CrossRef]

58. Wacklin, P.; Kaukinen, K.; Tuovinen, E.; Collin, P.; Lindfors, K.; Partanen, J.; Mäki, M.; Mättö, J. The duodenal microbiota composition of adult celiac disease patients is associated with clinical manifestation of the disease. Inflamm. Bowel Dis. 2013, 19, 934-941. [CrossRef]

59. Caminero, A.; Galipeau, H.J.; McCarville, J.L.; Johnston, C.W.; Bernier, S.P.; Russell, A.K.; Jury, J.; Herran, A.R.; Casqueiro, J.; Tye-Din, J.A.; et al. Duodenal bacteria from patients with celiac disease and healthy subjects distinctly affect gluten breakdown and immunogenicity. Gastroenterology 2016, 151, 670-683. [CrossRef]

60. De Palma, G.; Capilla, A.; Nadal, I.; Nova, E.; Pozo, T.; Varea, V.; Polanco, I.; Castillejo, G.; López, A.; Garrote, J.A.; et al. Interplay between human leukocyte antigen and the microbial colonization process of the newborn intestine. Curr. Issues Mol. Biol. 2010, 12, 1-10.

61. Ivarsson, A.; Hernell, O.; Stenlund, H.; Persson, L.A. Breast-feeding protects against celiac disease. Am. J. Clin. Nutr. 2002, 75, 914-921. [CrossRef] 
62. Palma, G.D.; Capilla, A.; Nova, E.; Castillejo, G.; Varea, V.; Pozo, T.; Garrote, J.A.; Polanco, I.; López, A.; Ribes-Koninckx, C.; et al. Influence of milk-feeding type and genetic risk of developing coeliac disease on intestinal microbiota of infants: The PROFICEL study. PLoS ONE 2012, 7, e30791. [CrossRef] [PubMed]

63. Silano, M.; Agostoni, C.; Sanz, Y.; Guandalini, S. Infant feeding and risk of developing celiac disease: A systematic review. BMJ Open 2016, 6, e009163. [CrossRef] [PubMed]

64. Lionetti, E.; Castellaneta, S.; Francavilla, R.; Pulvirenti, A.; Tonutti, E.; Amarri, S.; Barbato, M.; Barbera, C.; Barera, G.; Bellantoni, A.; et al. Introduction of gluten, HLA status, and the risk of celiac disease in children. N. Engl. J. Med. 2014, 371, 295-303. [CrossRef]

65. Nylund, L.; Kaukinen, K.; Lindfors, K. The microbiotas a component of the celiac disease and non celiac gluten sensitivity. Clin. Nutr. Exp. 2016, 6, 17-24. [CrossRef]

66. Namatovu, F.; Olsson, C.; Lindkvist, M.; Myléus, A.; Högberg, U.; Ivarsson, A.; Sandström, O. Maternal and perinatal conditions and the risk of developing celiac disease during childhood. BMC Pediatr. 2016, 16, 77. [CrossRef]

67. Kristensen, K.; Henriksen, L. Cesarean section and disease associated with immune function. J. Allergy Clin. Immunol. 2016, 137, 587-590. [CrossRef]

68. Marild, K.; Kahrs, C.R.; Tapia, G.; Stene, L.C.; Størdal, K. Infections and risk of celiac disease in childhood: A prospective nationwide cohort study. Am. J. Gastroenterol. 2015, 110, 1475-1484. [CrossRef]

69. Marild, K.; Ye, W.; Lebwohl, B.; Green, P.H.; Blaser, M.J.; Card, T.; Ludvigsson, J.F. Antibiotic exposure and the development of coeliac disease: A nationwide case-control study. BMC Gastroenterol. 2013, 13, 109. [CrossRef] [PubMed]

70. Pozo-Rubio, T.; de Palma, G.; Mujico, J.R.; Olivares, M.; Marcos, A.; Acuña, M.D.; Polanco, I.; Sanz, Y.; Nova, E. Influence of early environmental factors on lymphocyte subsets and gut microbiota in infants at risk of celiac disease; the PROFICEL study. Nutr. Hosp. 2013, 28, 464-473. [PubMed]

71. Canova, C.; Zabeo, V.; Pitter, G.; Romor, P.; Baldovin, T.; Zanotti, R.; Simonato, L. Association of maternal education, early infections and antibiotic use with celiac disease: A population based birth cohort study in northeastern Italy. Am. J. Epidemiol. 2014, 180, 76-85. [CrossRef]

72. Dudefoi, W.; Moniz, K.; Allen-Vercoe, E.; Ropers, M.H.; Walker, V.K. Impact of food grade and nano-TiO 2 particles on human intestinal community. Food Chem. Toxicol. 2017, 106, 242-249. [CrossRef] [PubMed]

73. Li, J.; Yang, S.; Lei, R.; Gu, W.; Qin, Y.; Ma, S.; Chen, K.; Chang, Y.; Bai, X.; Xia, S.; et al. Oral administration of rutile and anatase $\mathrm{TiO}_{2}$ nanoparticles shifts mouse gut microbiota structure. Nanoscale 2018, 10, 7736-7745. [CrossRef] [PubMed]

74. van den Brule, S.; Ambroise, J.; Lecloux, H.; Levard, C.; Soulas, R.; De Temmerman, P.J.; Palmai-Pallag, M.; Marbaix, E.; Lison, D. Dietary silver nanoparticles can disturb the gut microbiota in mice. Part. Fibre Toxicol. 2016, 13, 38. [CrossRef] [PubMed]

75. Pinto-Sanchez, M.I.; Verdu, E.F.; Liu, E.; Bercik, P.; Green, P.H.; Murray, J.A.; Guandalini, S.; Moayyedi, P. Gluten introduction to infant feeding and risk of celiac disease: Systematic review and meta-analysis. $J$. Pediatr. 2016, 168, 132-143. [CrossRef] [PubMed]

76. Herran, A.R.; Perez-Andres, J.; Caminero, A.; Nistal, E.; Vivas, S.; Ruiz de Morales, J.M.; Casqueiro, J. Gluten-degrading bacteria are present in human small intestine of healthy volunteers and celiac patients. Res. Microbiol. 2017, 168, 673-684. [CrossRef] [PubMed]

77. Olivares, M.; Laparra, M.; Sanz, Y. Influence of Bifidobacterium longum CECT 7347 and gliadin peptides on intestinal epithelial cell proteome. J. Agric. Food Chem. 2012, 59, 7666-7671. [CrossRef]

78. Hollon, J.; Puppa, E.L.; Greenwald, B.; Goldberg, E.; Guerrerio, A.; Fasano, A. Effect of gliadin on permeability of intestinal biopsy explants from celiac disease patients and patients with non-celiac gluten sensitivity. Nutrients 2015, 715, 1565-1576. [CrossRef]

79. Vorobjova, T.; Raikkerus, H.; Kadaja, L.; Talja, I.; Uibo, O.; Heilman, K.; Uibo, R. Circulating zonulin correlates with density of enteroviruses and tolerogenic dendritic cells in the small bowel mucosa of celiac disease Patients. Dig. Dis. Sci. 2017, 62, 358-371. [CrossRef]

80. Cinova, J.; DePalma, G.; Stepankova, R.; Kofronova, O.; Kverka, M.; Sanz, Y.; Tuckova, L. Role of intestinal bacteria in gliadin-induced changes in intestinal mucosa: Study in germ free rats. PLoS ONE 2011, 6, e16169. [CrossRef]

81. Cenit, M.C.; Codoner-Franch, P.; Sanz, Y. Gut Microbiota and risk of developing celiac disease. J. Clin. Gastroenterol. 2016, 50, 48-52. [CrossRef] 
82. Cukrowska, B.; Sowińska, A.; Bierła, J.B.; Czarnowska, E.; Rybak, A.; Grzybowska-Chlebowczyk, U. Intestinal epithelium, intraepithelial lymphocytes and the gut microbiota-Key players in the pathogenesis of celiac disease. World J. Gastroenterol. 2017, 14, 7505-7518. [CrossRef] [PubMed]

83. Pozo-Rubio, T.; Olivares, M.; Nova, E. Immune development and intestinal microbiota in celiac disease. Clin. Dev. Immunol. 2012, 2012, 654143. [CrossRef]

84. Hoffmanova, I.; Sanchez, D.; Tučková, L.; Tlaskalová-Hogenová, H. Celiac disease and liver disorders: From putative pathogenesis to clinical implications. Nutrients 2018, 10, 892. [CrossRef] [PubMed]

85. Ivanov, I.; Atarashi, K.; Manel, N.; Brodie, E.L.; Shima, T.; Karaoz, U.; Wei, D.; Goldfarb, K.C.; Santee, C.A.; Lynch, S.V.; et al. Induction of intestinal Th17 cells by segmented filamentous bacteria. Cell 2009, 139, 485-498. [CrossRef] [PubMed]

86. Hill, C.; Guarner, F.; Reid, G.; Gibson, G.R.; Merenstein, D.J.; Pot, B.; Morelli, L.; Canani, R.B.; Flint, H.J.; Salminen, S.; et al. The International Scientific Association for Probiotics and Prebiotics consensus statement on the scope and appropriate use of the term probiotic. Nat. Rev. Gastroenterol. Hepatol. 2014, 11, 506-514. [CrossRef]

87. De Sousa Moraes, L.F.; Grzeskowiak, L.M.; de Sales Teixeira, T.F.; Carmo, M.; Peluzio, G. Intestinal microbiota and probiotics in celiac disease. Clin. Moicrobiol. Rev. 2014, 27, 482-489. [CrossRef]

88. Rizzello, C.G.; De Angelis, M.; Di Cagno, R.; Camarca, A.; Silano, M.; Losito, I.; De Vincenzi, M.; De Bari, M.D.; Palmisano, F.; Maurano, F; et al. Highly efficient gluten degradation by lactobacilli and fungal proteases during food processing: New perspectives for celiac disease. Environ. Appl. Microbiol. 2007, 73, 4499-4507. [CrossRef]

89. Duar, R.M.; Clark, K.J.; Patil, P.B.; Hernández, C.; Brüning, S.; Burkey, T.E.; Madayiputhiya, N.; Taylor, S.L.; Walter, J. Identification and characterization of intestinal lactobacilli strains capable of degrading immunotoxic peptides present in gluten. J. Appl. Microbiol. 2014, 118, 515-522. [CrossRef]

90. Mandile, R.; Picascia, S.; Parrella, C.; Camarca, A.; Gobetti, M.; Greco, L.; Troncone, R.; Gianfrani, C.; Auricchio, R. Lack of immunogenicity of hydrolysed wheat flour in patients with coeliac disease after a short-term oral challenge. Aliment. Pharmacol. Ther. 2017, 46, 440-446. [CrossRef]

91. Francavilla, R.; De Angelis, M.; Rizzello, C.G.; Cavallo, N.; Dal Bello, F.; Gobbetti, M. Selected Probiotic Lactobacilli Have the Capacity To Hydrolyze Gluten Peptides during Simulated Gastrointestinal Digestion. Appl. Environ. Micribiol. 2017, 83, e00376. [CrossRef]

92. Angelis, M.D.; Rizzello, C.G.; Fasano, A.; Clemente, M.G.; De Simone, C.; Silano, M.; De Vincenzi, M.; Losito, I.; Gobbetti, M. VSL\#3 probiotic preparation has the capacity to hydrolyze giiadin polyppeptide responsible for celiac sprue. Biochem. Biophys. Acta 2006, 1762, 80-93. [PubMed]

93. Lindfors, K.; Blomqvist, T.; Juuti-Uusitalo, K.; Stenman, S.; Venäläinen, J.; Mäki, M.; Kaukinen, K. Live probiotic Bifidobacterium lactis bacteria inhibit the toxic effects induced by wheat gliadin in epithelial cell culture. Clin. Exp. Immunol. 2008, 152, 552-558. [CrossRef] [PubMed]

94. Laparra, J.M.; Sanz, Y. Bifidobacteria inhibit the inflammatory response induced by gliadins in intestinal epithelial cells via modifications of toxic peptide generation during digestion. J. Cell. Biochem. 2010, 109, 801-807. [CrossRef] [PubMed]

95. Medina, M.; De Palma, G.; Ribes-Koninckx, C.; Calabuig, M.; Sanz, Y. Bifidobacterium strains suppress in vitro the pro-inflammatory milieu triggered by the large intestinal microbiota of coeliac patients. J. Inflamm. 2008, 5, 19. [CrossRef] [PubMed]

96. Papista, C.; Gerakopoulos, V.; Kourelis, A.; Sounidaki, M.; Kontana, A.; Berthelot, L.; Moura, I.C.; Monteiro, R.C.; Yiangou, M. Gluten induces coeliac-like disease in sensitised mice involving IgA, CD71 and transglutaminase 2 interactions that are prevented by probiotics. Lab. Investig. 2012, 92, 625-635. [CrossRef]

97. Olivares, M.; Laparra, M.; Sanz, Y. Oral administration of Bifidobacterium longum CECT 7347 modulates jejunal proteome in an in vivo gliadin-induced enteropathy animal model. J. Proteom. 2012, 77, 310-320. [CrossRef]

98. McCarville, A.; Dong, J.; Caminero, A.; Bermudez-Brito, M.; Jury, J.; Murray, J.A.; Steinmann, M.; Delley, M.; Tangyu, M.; Langella, P.; et al. Commensal Bifidobacterium longum Strain Prevents Gluten-Related Immunopathology in Mice through Expression of a Serine Protease Inhibitor. J. Appl. Environ. Microbiol. 2017, 83, e01323. [CrossRef]

99. D'Arienzo, R.; Maurano, F.; Lavermicocca, P.; Ricca, E.; Rossi, M. Modulation of the immune response by probiotic strains in a mouse model of gluten sensitivity. Cytokine 2009, 48, 254-259. [CrossRef] 
100. Orlando, A.; Linsalata, M.; Bianco, G.; Notarnicola, M.; D'Attoma, B.; Scavo, M.P.; Tafaro, A.; Russo, F. Lactobacillus rhamnosus GG protects the epithelial barrier of wistar rats from the pepsin-trypsin-digested gliadin (PTG)-induced enteropathy. Nutrients 2018, 10, 1698. [CrossRef]

101. D'Arienzo, R.; Maurano, F.; Luongo, D.; Mazzarella, G.; Stefanile, R.; Troncone, R.; Auricchio, S.; Ricca, E.; Chella, D.; Rossi, M. Adjuvant effect of Lactobacillus casei in a mouse model of gluten sensitivity. Immunol. Lett. 2008, 119, 78-83. [CrossRef]

102. D'Arienzo, R.; Stefanile, R.; Maurano, F.; Mazzarella, G.; Ricca, E.; Troncone, R.; Auricchio, S.; Rossi, M. Immunomodulatory effects of Lactobacillus casei administration in a mouse model of gliadin-sensitive enteropathy. Scand. J. Immunol. 2011, 74, 335-341. [CrossRef] [PubMed]

103. Laparra, J.M.; Olivares, M.; Gallina, O.; Sanz, Y. Bifidobacterium longum CECT 7347 modulates immune responses in gliadin-induced enteropathy animal model. PLoS ONE 2012, 7, e30744. [CrossRef] [PubMed]

104. Lorenzo Pisarello, M.J.; Vintiñi, E.O.; González, S.N.; Pagani, F.; Medina, M.S. Decrease in lactobacilli in the intestinal microbiota of celiac children with a gluten-free diet, and selection of potentially probiotic strains. Can. J. Microbiol. 2015, 61, 32-37. [CrossRef] [PubMed]

105. Smecuol, E.; Hwang, H.J.; Sugai, E.; Corso, L.; Cherñavsky, A.C.; Bellavite, F.P.; González, A.; Vodánovich, F.; Moreno, M.L.; Vázquez, H.; et al. Exploratory, randomized, double-blind, placebo-controlled study on the effects of Bifidobacterium infantis Natren life start strain super strain in active celiac disease. J. Clin. Gastroenterol. 2013, 47, 139-147. [CrossRef] [PubMed]

106. Olivares, M.; Castillejo, G.; Varea, V.; Sanz, Y. Double-blind, randomized, placebo controlled intervention trial to evaluate the effects of biofidbacterium longm CECT 7347 in children with newly diagnosed coeliac disease. Br. J. Nutr. 2014, 112, 30-40. [CrossRef]

107. Klemenak, M.; Dolinšek, J.; Langerholc, T.; Di Gioia, D.; Mičetić-Turk, D. Administration of Bifidobacterium breve decreases the production of TNF- $\alpha$ in children with celiac disease. Dig. Dis. Sci. 2015, 60, 3386-3392. [CrossRef]

108. Quagliariello, A.; Cionci, N.B.; Luiselli, D.; D’Auria, G.; Martinez-Priego, L.; Pérez-Villarroya, D.; Langerholc, T.; Primec, M.; Mičetić-Turk, D.; Di Gioia, D. Effect of Bifidobacterium breve on the intestinal microbiota of coeliac children on a gluten free diet: A pilot study. Nutrients 2016, 8, 660. [CrossRef]

109. Harnett, J.; Myers, S.P.; Rolfe, M. Probiotics and the microbiome in celiac disease: A randomised controlled trial. Evid. Based Complement. Altern. Med. 2016, 2016, 9048574. [CrossRef]

110. Pinto-Sánchez, M.I.; Smecuol, E.C.; Temprano, M.P.; Sugai, E.; González, A.; Moreno, M.L.; Huang, X.; Bercik, P.; Cabanne, A.; Vázquez, H.; et al. Bifidobacterium infantis NLS Super strain reduces the expression of $\alpha$-defensin-5, a marker of innate immunity, in the mucosa of active celiac Disease patients. J. Clin. Gastroenterol. 2017, 51, 814-817. [CrossRef]

111. Primec, M.; Klemenak, M.; Di Gioia, D.; Aloisio, I.; Bozzi Cionci, N.; Quagliariello, A.; Gorenjak, M.; Mičetić-Turk, D.; Langerholc, T. Clinical intervention using Bifidobacterium strains in celiac disease children reveals novel microbial modulators of TNF- $\alpha$ and short-chain fatty acids. Clin. Nutr. 2019, 38, 1373-1381. [CrossRef]

112. Francavilla, R.; Piccola, M.; Francavilla, A.; Polimeno, L.; Semeraro, F.; Cristofori, F.; Castellaneta, S.; Barone, M.; Indrio, F.; Gobbetti, M.; et al. Clinical and microbiological effect of a multispecies probiotic supplementation in celiac patients with persistent IBS-type symptoms: A randomized, double-blind, placebo-controlled, multicenter trial. J. Clin. Gastroenterol. 2019, 53, e117-e125. [CrossRef] [PubMed]

113. Martinello, F.; Roman, C.M.; de Souza, P.A. Effects of probiotic intake on intestinal bifidobacteria of celiac patients. Arq. Gastroenterol. 2017, 54, 85-90. [CrossRef] [PubMed]

114. Uusitalo, U.; Aronsson, C.A.; Liu, X.; Kurppa, K.; Yang, J.; Liu, E.; Skidmore, J.; Winkler, C.; Rewers, M.J.; Hagopian, W.A.; et al. Early probiotic supplementation and the risk of celiac disease in children at genetic risk. Nutrients 2019, 11, 1790. [CrossRef] [PubMed]

115. Cionci, N.B.; Baffoni, L.; Gaggia, F.D.; Gioia, D. Therapeutic Microbiology: The Role of Bifidobacterium breve as food supplement for the prevention/treatment of paediatric diseases. Nutrients 2018, 10, 1723. [CrossRef]

116. Girbovan, A.; Sur, G.; Samasca, G.; Lupan, I. Dysbiosis a risk factor for celiac disease. Med. Microbiol. Immunol. 2017, 206, 83-91. [CrossRef]

117. Serena, G.; Fasano, A. Use of probiotics to prevent celiac disease and IBD in pediatrics. Adv. Exp. Med. Biol. 2019, 1125, 69-81. 
118. Yoosuf, S.; Makharia, G.K. Evolving therapy for celiac disease. Front. Pediatr. 2019, 7, 193. [CrossRef]

119. Pace, L.A.; Crowe, S.E. Complex relationships between food, diet, and the microbiome. Gastroenterol. Clin. North Am. 2016, 45, 253-265. [CrossRef] 